\title{
ON THE STRUCTURE OF THE GRADUATION THESIS “ ON THE PHYSICAL DEVELOPMENT OF SCHOOL STUDENTS OF THE TOWN OF TARTU" DEFENDED AT THE DEPARTMENT (FORMER CHAIR) OF ZOOLOGY AT THE UNIVERSITY OF TARTU (FORMER TARTU STATE UNIVERSITY) IN 1958
}

\author{
JaAn Kasmel, Tiiu Kasmel \\ Centre for Physical Anthropology, University of Tartu, Tartu, Estonia
}

\begin{abstract}
Throughout times, along with simpler papers (essays, reports, subject and research papers), students of different specialities at the University of Tartu have also done more serious research in many areas, including anthropology, under the supervision of lecturers.

More than a quarter of century ago, before 1991, the students of the Soviet-time Tartu State University wrote, in addition to exercises in research, term papers, graduation theses and prize essays of Students Scientific Society (founded in 1948) [10].

The article will deal with 10 graduation theses compiled at the Chair of Zoology of Tartu State University from 1958-1970. These papers addressed Estonian school students' physical development based on anthropological material collected from 1956-1967 [9].

In those years, the graduation thesis was a student's independent research paper which was defended in front of a state examination board to complete the studies at the university [3].

Particular attention is paid to the first of these graduation theses - the graduation thesis defended by 5th-year student Viivi Schüts in 1958, "On the physical development of school students of the town of Tartu" (in Estonian, on 94 pages in typescript, hard-cover). The article includes the structure of this research paper [8].
\end{abstract}

Keywords: Juhan Aul; Viivi Schüts; Evi-Mai Kirhäiding; Leiu Heapost 
In the middle of the past 20th century there were no common standards for the assessment of physical development of Estonian school students. In practice (schools, hospitals, sports, etc) either Russian or German standard tables were used. These, however, proved unsuitable in our circumstances, as the anthropological variables of each ethnicity reflect only the physical development of this ethnicity correctly.

To fill this gap, the standard tables for assessment of Tallinn school students' physical development were first published in E. Närska's study in 1956 [6].

In earlier times, data on Estonian school student's physical development had been collected by Juhan Aul in 1932-1940, but because of the war, his work remained unfinished; his data were not analysed or published in print [1].

Therefore, the questions of studying Estonian school student's physical development were included in the thematic research plan of the Chair of Zoology at Tartu State University (now the University of Tartu). Research was supervised by Associate Professor J. Aul [2].

To collect data, annual expeditions were arranged to different towns and rural districts of Estonia, mainly in September. Most measurements were performed by J. Aul in person, to avoid the differences that inevitably occur if several persons take the measurements. Therefore, these anthropological data can be considered particularly valuable.

The measurements were performed according to the generally recognised rules of R. Martin and with the instruments introduced by him.

An individual anthropological observation sheet was filled for each student measured. In addition to personal data, anthropological measurements were recorded. The following of them were used in graduation theses: general body height or stature, shoulder height, finger height, chest breadth and depth, hips breadth, chest circumference, head length and breadth, morphological face height, weight (body mass), vital capacity of lungs, right hand squeeze.

At some schools which had no medical scales, students could not be weighed.

The following descriptive variables were assessed: constitution type, colour of eyes and hair (according to Fischer-Saller and Martin-Schultz scales), nose bridge shape, and development of breasts (in girls).

Students were divided into groups according to their age. 1-6 months were not added to the number of years, but in the case of bigger number of months, the number of years was increased by one. For example, the group of 7-yearolds included students whose age was from 6 years and more than 6 months to 7 years and 6 months. 
At variation statistical analysis of the material, the arithmetic mean $(M)$, mean error $(\mathrm{m})$, square deviation or standard deviation $(\delta)$ and variation coefficient $(\mathrm{v})$ of each measurement or index was calculated.

The means of body measurements were given in centimetres, those of the head and face - in millimetres.

For individual body measurements, the relative values (to observe body proportions) were also calculated from the corresponding mean values.

Individually, six indices were calculated: relative sitting height, body corpulence index or Buffon-Rohrer index, thoracic index, head length-breadth index or head index, morphological facial index, sexual dimorphism index (SDI - percentage of girls' measurement from boys' measurement).

In graduation theses, the changes in anthropological variables and indices were depicted graphically.

Correlations were calculated for body height and body mass, and body height and chest circumference. Correlation tables give the correlation coefficient ( $\mathrm{r}$ ) and regression coefficients $\mathrm{Ry} / \mathrm{x}$ and $\mathrm{Rx} / \mathrm{y}$.

As known, the correlation coefficient gives us an idea of the value of the correlation between the given measurements (it can vary between 0 and \pm 1 ).

The first of the regression coefficients mentioned shows how much the dependent variable (y) increases if the independent variable (here, body height $\mathrm{x}$ ) increases by one unit.

To compare the measurement data between groups, the arithmetic means of arithmetic means of different age groups were used. For comparison, the groups of the same age were used.

To assess the individual values of each measurement, $\pm 2,5 \delta$ was taken as the variance range of the measurement, as it includes $98.7 \%$ of the subjects measured, i.e. nearly all the subjects. This treatment of the variance range was used for practical reasons - if the variance range is divided into five groups (which is the most usual and practical division), then the size of each group equals $\delta[8]$.

The anthropometric variables used can be divided into the following groups:

1. General body measurements: body height, body mass, relation between body height and mass.

2. Trunk measurements: sitting height, relative sitting height, shoulder breadth, chest circumference, chest breadth, chest depth, chest index, hips breadth.

3. Extremities measurements: upper extremity length. 
4. Head measurements: head length, head breadth, head length-breadth index, face breadth, morphological face height, morphological facial index.

5. Functional variables: lungs vital capacity, right hand squeeze (dynamometry).

All auxiliary tasks, observations and part of the measurements were performed by expedition members - students of the Department of Biology specialising in zoology. Analysis of data according to regions was performed by expedition members who wrote term papers and graduation theses based on them.

In those years, the graduation thesis was an independent research paper of the 5th-year student of the Department of Zoology. It was defended in front of a state examination board to complete the studies at the university [3].

Accordingly, to graduate from the university, Viivi Schüts, a 5th-year student of zoology submitted her graduation thesis "On physical development of school students of the town of Tartu" (94 pages, hard cover) in spring 1958 [8].

She had participated in anthropological measuring of school students of the town of Tartu in 1956 and 1957.

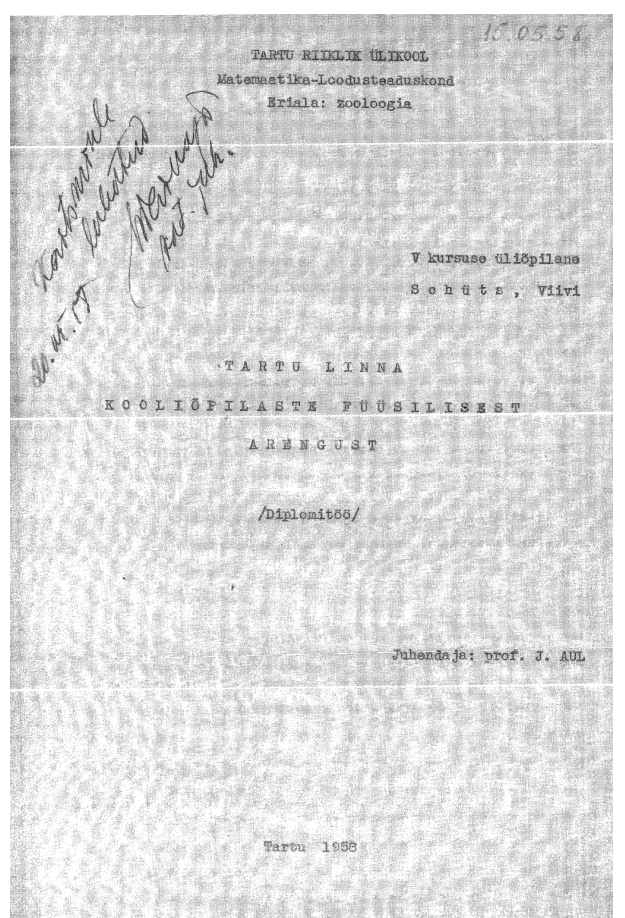

Figure 1. Title page of student V. Schüts' graduation thesis "On the physical development of school students of the town of Tartu" (1958) Measuring was performed at four secondary schools of Tartu (no. 1, 2, 3 and 5), four 7-year schools (7., 8., 10. and 11.), the Training School of Tartu Pedagogical School, Tartu Medical Secondary School and Vocational School of Building No 21.

Students attending forms 1-11 were measured. They were of Estonian ethnicity and their parents' permanent residence was the town of Tartu. In total, 2906 students were measured - 1512 girls and 1394 boys aged 7-18 years.

The research paper begins with the title page, which includes the name of the university (in capital letters), name of the faculty, speciality of the compiler of the graduation thesis, year of studies, surname and first name of the student author, 
title of the paper (in capital letters), type of paper: graduation thesis, data on the supervisor (position, first name and surname), place and year of writing the paper [8].

From the title page and the following contents page of V. Schüts' graduation thesis, we can get an overview of the structure of this research paper, which is presented below:

\section{CONTENTS}

P.

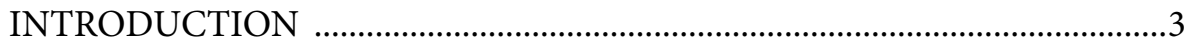

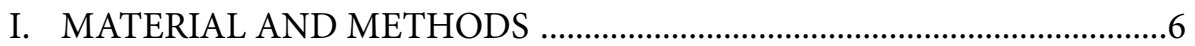

II. DATA ON INDIVIDUAL MEASUREMENTS ..........................................6

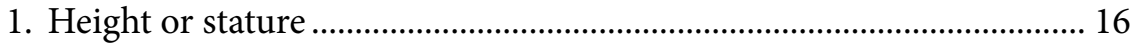

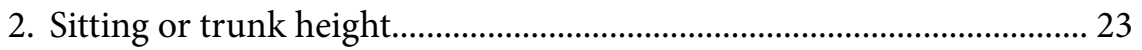

Scelia index....................................................................... 25

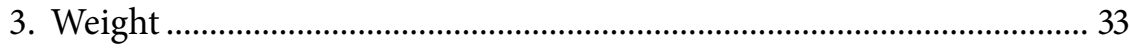

Body corpulence or Buffon-Rohrer index ................................ 35

4. Trunk measurements ............................................................................ 44

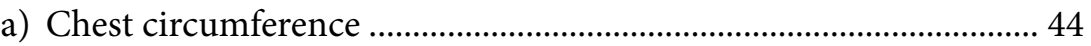

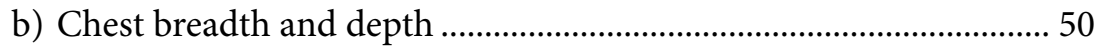

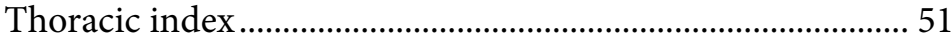

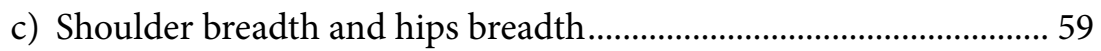

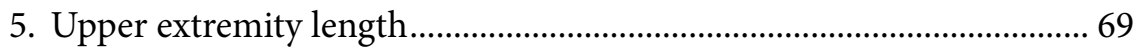

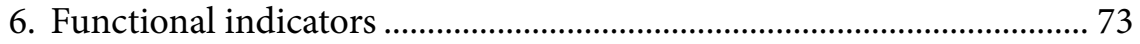

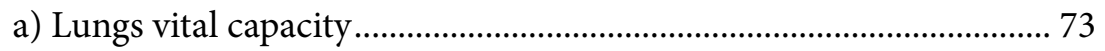

b) Strength of right hand muscles (dynamometry) ............................ 75

7. Head measurements ................................................................................ 79

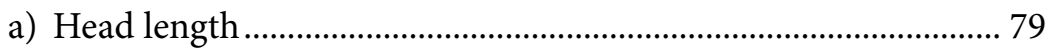

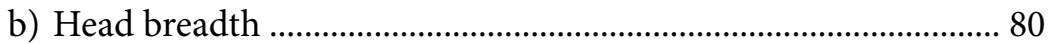

Head length-breadth index or head index .................................. 80

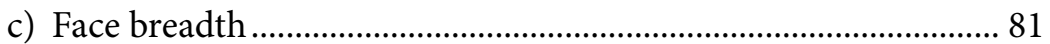

d) Morphological face height ........................................................... 82

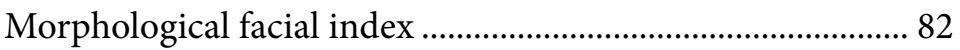

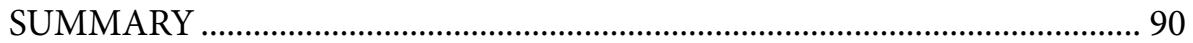

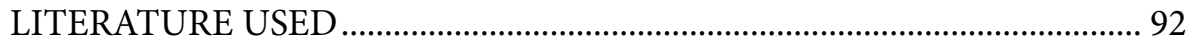




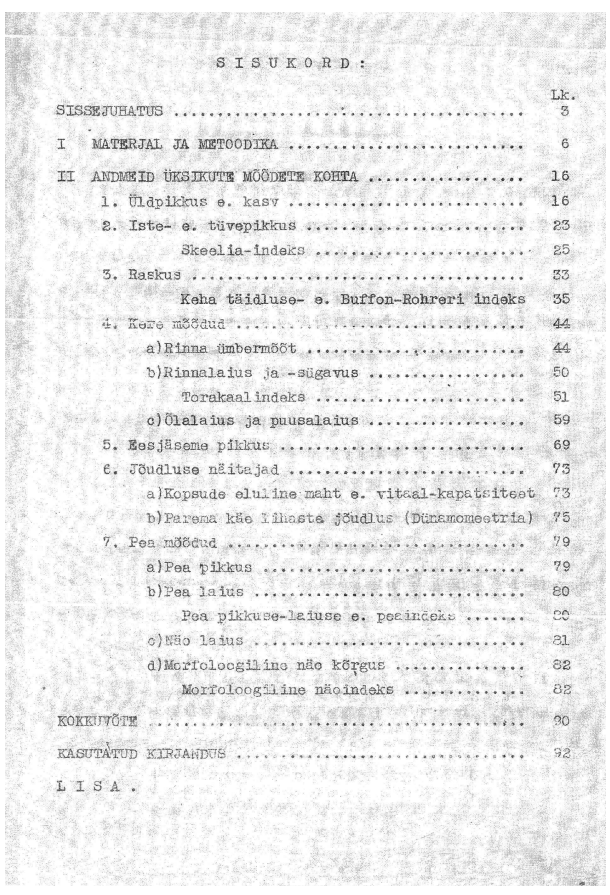

Figure 2. Contents of student V. Schüts' graduation thesis "On the physical development of school students of the town of Tartu" (1958)
The Appendix includes 24 tables on 12 pages:

1. standard tables for assessment of individual physical development of Estonian girls and boys in different age groups;

2. tables of correlations between height and body mass, and height and chest circumference [8].

In spring 1959, 5th-year student Evi-Mai Kirhäiding submitted her graduation thesis on the theme "On physical development of students of schools of general education in Tartu and Elva districts", on 116 pages, hard-cover [5].

The author of this paper had participated in anthropological measuring of Estonian school students in both the town of Tartu and Tartu and Elva districts; in these rural

districts, the measuring was performed in 1956-1958 (mainly in September).

The measurements were taken in 11 7-year schools and 5 secondary schools of Tartu and Elva districts. Some students from these rural districts were measured in the secondary schools of the town of Tartu.

The contents of this graduation thesis include an additional section (8), which presents an overview of correlations between height and weight, and height and chest circumference [5].

Neither V. Schüts' nor E.-M. Kirhäiding's graduation theses have a summary in a foreign language.

The list of Professor Juhan Aul's publications (Professor Juhan Auli kirjanduse nimestik 1919-1997, 1997) presents a list of all the 21 graduation thesis supervised by him in 1949-1976 [7].

Ten of them, from 1958-1970, deal with physical development of Estonian school students in two towns (Tartu and Pärnu) and nine rural districts of that time (Tartu, Elva, Põlva, Räpina, Rapla, Keila, Pärnu, Võru and Harju); the anthropological material was collected from there from 1956-1966 [9]. 
In addition, Leiu Heapost wrote her Candidate of Biology thesis "Physical development of Tallinn school students", which was defended in 1976. The material for it dates from 1966-1969 [4].

In 1982, Prof. J. Aul published a monograph on Estonian school students' anthropology (Eesti kooliópilaste antropoloogia) on 139 pages, which sums up the analysis of the anthropological material collected in 1956-1967 [2].

These research papers show that even today they could be used to find additional data on Estonian school students' physical anthropology 50 years ago.

\section{REFERENCES}

1. Aul J. (1973). Eesti kooliõpilaste füüsilisest arengust aastail 1932-1940. Loodusuurijate Seltsi Aastaraamat, 2, 191-222.

2. Aul J. (1982). Eesti kooliõpilaste antropoloogia. Tallinn.

3. Diplomitöö (1987). Eesti Nõukogude Entsüklopeedia. Tallinn: Valgus, 2, 128.

4. Heapost L. (1984). Tallinna kooliõpilaste ealine antropoloogia (1966-1969). Tallinn: Valgus.

5. Kirhäiding E.-M. (1959). Tartu ja Elva rajooni üldhariduslike koolide õpilaste füüsilisest arengust. Tartu.

6. Närska E. (1956). Tallinna kooliõpilaste füüsiline areng. Nõukoguse Eesti Tervishoid, 5, 107-117.

7. Professor Juhan Aul. Kirjanduse nimestik 1919-1997 (1997). Tartu.

8. Schüts V. (1958). Tartu linna kooliõpilaste füüsilisest arengust. Tartu.

9. Zooloogia kateedi diplomitööde bibliograafia 1949-1986 (1986). Tartu.

10. Universitas Tartuensis 1632-2007 (2007). Tartu.

\section{Address for correspondence:}

Jaan Kasmel

Centre for Physical Anthropology

University of Tartu

Struve 2, Tartu 51003, Estonia

E-mail: jaanjkasmel@hot.ee 